\title{
Molecular evidence of mother-to-child transmission of HTLV-IIc in the Kararao Village (Kayapo) in the Amazon Region of Brazil
}

\author{
Evidência molecular da transmissão do HTLV-IIc de mãe para filho, na aldeia Kararao \\ (Kayapó), na região amazônica brasileira
}

\author{
Ricardo Ishak', Antonio Carlos R. Vallinoto', Vânia Nakauth Azevedo', Martha Lewis², \\ William W. Hall ${ }^{2}$ and Marluísa O. Guimarães Ishak'
}

\begin{abstract}
Blood samples from native Indians in the Kararao village (Kayapo), were analysed using serological and molecular methods to characterize infection and analyse transmission of HTLV-II. Specific reactivity was observed in 3/26 individuals, of which two samples were from a mother and child. RFLP analysis of the pX and env regions confirmed HTLV-II infection. Nucleotide sequence of the 5'LTR segment and phylogenetic analysis showed a high similarity (98\%) between the three samples and prototype HTLV-Ila (Mot), and confirmed the occurrence of the HTLV-llc subtype. There was a high genetic similarity (99.9\%) between the mother and child samples and the only difference was a deletion of two nucleotides (TC) in the mother sequence. Previous epidemiological studies among native Indians from Brazil have provided evidence of intrafamilial and vertical transmission of HTLV-IIc. The present study now provides molecular evidence of mother-to-child transmission of HTLV-IIc, a mechanism that is in large part responsible for the endemicity of HTLV in these relatively closed populations. Although the actual route of transmission is unknown, breast feeding would appear to be most likely.

Key-words: HTLV-II. Molecular epidemiology. Vertical transmission. Amerindian populations.
\end{abstract}

Resumo Amostras de sangue de índios nativos na aldeia Kararao (Kayapó) foram analisadas, usando-se métodos sorológico e molecular, para caracterizar a infecção e analisar a transmissão do HTLV-II. Observouse reatividade específica em 3/26 indivíduos, dos quais duas amostras eram de uma mãe e de seu filho. A análise pela RFLP de regiões $\mathrm{pX}$ e env confirmou a infecção pelo HTLV-II. A seqüência de nucleotídios do segmento 5'LTR e a análise filogenética mostraram alta similaridade (98\%) entre as três amostras e o protótipo HTLV-IIa (mot) e confirmaram a ocorrência do subtipo HTLV-Ilc. Houve uma alta similaridade genética (99,9\%) entre as amostras da mãe e do filho e a única diferença foi uma deleção de dois nucleotídios (TC) na seqüência materna. Estudos epidemiológicos anteriores entre índios nativos do Brasil forneceram prova da transmissão intrafamilial e vertical do HTLV-Ilc. O presente estudo fornece evidência molecular da transmissão do HTLV-IIc de mãe para filho, um mecanismo que em grande parte é responsável pela endemicidade do HTLV nessas populações epidemiologicamente fechadas. Embora a verdadeira via de transmissão seja desconhecida, a amamentação materna poderia ser a mais provável.

Palavras-chaves: HTLV-II. Epidemiologia molecular. Transmissão vertical. Populações ameríndias.

Human T-cell lymphotropic virus, types I and II (HTLVI and HTLV-II), is endemic in several different geographical regions and its infection in the human host is associated to hematological and neurological disorders ${ }^{13}{ }^{1526}$. HTLV-II is endemic among intravenous drug users from North and South America, Europe, Southeast Asia and in a large number of native Indian groups throughout the Americas and certain pygmy groups in Africa' 2412131617252729 .
HTLV-I and HTLV-II infections among urban populations are maintained through blood transfusions, drug usage, and sexual intercourse as their most important routes of transmission ${ }^{1121}$. However, in several Indian populations, mother-to-child transmission has been reported as the main route of transmission and maintenance of endemicity of HTLV-II211 1730 .

The present paper describes the occurrence of HTLVIIc, in three individuals from the Kararao tribe (Kayapo) and the molecular evidence of vertical transmission of this virus.

\footnotetext{
1. Laboratório de Virologia do Centro de Ciências Biológicas da Universidade Federal do Pará, Belém, PA, Brasil; 2. Laboratory of Medical Virology, University College, Dublin, Ireland.

Address to: Dr. Ricardo Ishak. Caixa Postal 13005, 66040-970, Belém, PA, Brazil,

Tel.: 5591 211-1587, Fax 5591 249-0373

e-mail:rishak@canal13.com.br

Recebido para publicação em 17/5/2001.
} 


\section{MATERIAL AND METHODS}

Population Examined and Samples. Blood samples were collected from twenty-four subjects residing in the Kararao tribe (Kayapo), a Je speaking community, located in the State of Para, Brazil. All the subjects had a sample of blood drawn and placed in tubes without anticoagulant to obtain serum and in other tubes containing HESPAN (Du Pont, USA) in order to separate peripheral blood mononuclear cells (PBMC). Serum and PBMC were stored at $-20^{\circ} \mathrm{C}$ before use.

Serological Assays.Serum samples were screened for the presence of antibodies to HTLV-I/II using an enzyme immunoassay (EIA, Ortho Diagnostic, USA) and the positive samples were further analyzed by Western blot (Genelab 2.4, Singapore) which permits differentiation of HTLV-I and HTLV-II serorreactivity.

Polymerase Chain Reaction (PCR) and Restriction Fragment Length Polymorphism (RFLP) Analysis. DNA was extracted from PBMC from HTLV-II serorreactive samples, and was used in a nested PCR to amplify part of the $p X$ region. The first round PCR was carried out using $1 \mu \mathrm{g}$ of the extracted DNA, $125 \mu \mathrm{M}$ of each dNTP (Perkin-Elmer, USA), $20 \mathrm{pmol} / \mu \mathrm{L}$ of each of the two external primers and 10x PCR buffer $-\mathrm{MgCl}_{2}$ (Perkin-Elmer, USA), ending up with a final volume of $50 \mu \mathrm{L}$. The reaction was incubated in a thermocycler (Perkin-Elmer, USA) for five minutes at $94^{\circ} \mathrm{C}$, followed by 35 cycles at $94^{\circ} \mathrm{C}$ ( 40 seconds), $51.6^{\circ} \mathrm{C}$ (30 seconds), $72^{\circ} \mathrm{C}$ (40 seconds) and extended for 10 minutes at $72^{\circ} \mathrm{C}$.

Five microliters of the amplified product were used in the nested PCR using a set of internal primers, and maintaining the same mixture (with a final volume of $100 \mu \mathrm{L}$ ), and the same temperature and incubation periods employed in the first reaction. The external primers sequences were 5'TTCCCAGGGTTTGGACAGAG-3' (nucleotides 7219-7238) and 5'-GGGTAAGGACCTTGAGGGTC-3' (nucleotides 7483-7464). The internal primers sequences were 5'CGGATACCCAGTCTACGTGTT-3' (nucleotides 72487268) and 5'-GAGCCGATAACGCGTCCATCG-3' (nucleotides 7406-7386). The two amplified products were analysed by electrophoresis in $2 \%$ agarose gels.

RFLP typing of this product (159 bp for both HTLV-I and HTLV-II) was performed by incubating the reaction product $(10 \mu \mathrm{L})$ with $0.4 \mu \mathrm{L}$ of the restriction endonuclease enzyme $\mathrm{Taql}$ and incubating at $65^{\circ} \mathrm{C}$ for at least 5 hours. The restriction site for the enzyme (T/CGA) is present in the amplified product of HTLV-II, generating two bands ( $85 \mathrm{bp}$ and $53 \mathrm{bp}$ ) that are visualized following an electrophoresis in a $3 \%$ agarose gel. HTLV-I lacks this particular site.

The subtyping of HTLV-II was obtained using a nested PCR, with two sets of primers that match a conservative nucleotide sequence flanking the env region, and coding for the envelope protein, as previously described ${ }^{714}$. The PCR product (631 bp) was digested enzymatically by $X$ Xhol. The RFLP pattern obtained discriminates between HTLV-Ila and HTLV-Ilb subtypes by the presence of the
C/TCGAG site in the HTLV-Ila. This is evidenced by the presence of two fragments (179 and 452bp) that are visualized on a $3 \%$ agarose gel electrophoresis.

Following the subtyping, all samples initially characterized as HTLV-lla were submitted to a nested PCR to $5^{\prime} L T R$ region, as previously described ${ }^{7}$ with two sets of primers, 5'- TCGCGATGACAATGGCGACTAGCCTC-3' and 5'-GGGGGCTTTGGGTATTGGAGTTGGG-3', corresponding to nucleotides $1-26$ and $855-831$ to the first step and 5'- GCCTCCCAAGCCAGCCAC-3' and 5'GGGAAAGCCCGTGGATTTGCCCCAT-3' in a second step, corresponding to nucleotides 16-33 and 831-807 from HTLV-II MoT strain. Following the amplification, the LTR fragment was electrophoresed on a $0.8 \%$ agarose gel and purified by QIA Quick Purification Kit (Quiagene,USA). The LTR PCR fragments were directly cloned into $\mathrm{PCR}^{\mathrm{TM}} \mathrm{II}$ (Introgen Original TA Cloning Kit) following the manufacturer's instructions. Plasmid DNA was prepared from recombinant clones using Wizard Miniprep kit (Promega) prior to sequencing of the product.

Nucleotide Sequence Analysis. Sequencing of 5'LTR was carried out using the vector-based primers M13R and T7 and internal sequence primers designed from the published HTLV-Ila MoT sequence. The samples were sequenced automatically with a PerkinElmer/ABI Prism 377 DNA Stretch Sequencer using Taq FS dye terminator cycle sequencing (Perkin-Elmer Cetus, Norwalk, California).

Phylogenetic Analysis. The nucleotide sequences originated from the $5^{\prime} L T R$ region (630 bp), obtained in the present study (Genbank Accession Number: KAA8878, Kararao, AF306731; KAA8879, Kararao, AF306732; KAA8883, Kararao, AF306733), were used to establish the phylogenetic relationship together with the twenty-six following HTLV-II strains described in the Genbank: MO, USA, M10060; NRA, USA, L20734; PYGCAM-1, Cameroon, Pygmy, Z46888; PH230PCAM, Cameroon, Z46838; ATL18, Georgia, U10252, BRAZ.A21, Brazil, U10253, LA8A, California, U10256, NOR2N, Norway, U10258, PUEB.AG and PUEB.RB, New Mexico, Pueblo, U10261, U10262, ITA47A and ITA50A, Italy, U10254, U10255, NY185, New York, U10259, PENN7A, Pennsylvania, U10260, SEM1050 and SEM1051, Florida, Seminole, U10263, U10264, SPAN129 and SPAN130, Spain, U10265, U10266; WYU2, Colombia, Wayu, U12794; GHKT, Ghana, L42507, KAY73 and KAY139, Kayapo, Amerindian, L42509, L42508; Pygmy-2, Efe Bambuti Pygmy tribe, Congo, Y14365. The sequence alignments were performed using the Eyeball Sequence Editor ${ }^{3}$. The phylogenetic relationship was performed by the Phylogenetic Inference Package - PHYLIP 3.5v8. The Neighbor-joining (NJ) method was used for the tree construction considering the standard Kimura twoparameter model. The statistical reliance of the tree was evaluated using 2000 bootstrap samples. 


\section{RESULTS}

Serology. Specific serorreactivity to HTLV-II was observed in three individuals from the Kararao tribe. Two samples were mother and child (KAA8878 and KAA8879, respectively), as observed in Figure 1. Serorreactivity to HTLV-II was confirmed by Western blot.
Molecular Characterization. PCR amplification of the $p X$ genomic region, followed by enzymatic digestion using Taql endonuclease confirmed HTLV-II infection among the Kararao indians. The amplification of env and subsequent restriction analysis with Xhol exhibited the

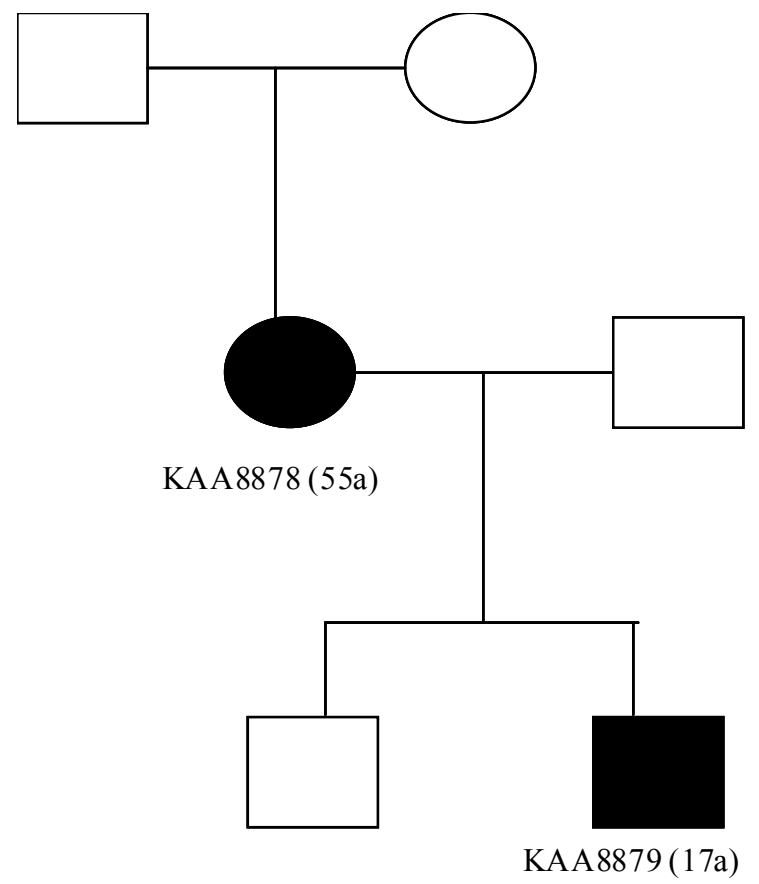

Figure 1 - Dendogram showing evidence of vertical transmission of HTLV-Il in the Kararao village

presence of two fragments (179bp and 492bp) as it is currently described as HTLV-II, subtype a.

Nucleotide sequence analysis (Figure 2) of the 5'LTR segment showed a high similarity (98\%) between the Kararao samples and the prototype Ila (HTLV-II-Mot). However, a consistent divergence (95\%) in nucleotide sequences was observed from the prototype Ilb (HTLVII-NRA). The differences found between Kararao virus and the prototype Mot sequences were characterized mainly by point mutation without large deletion or insertion. Significant changes in regulatory elements of the viral replication such as TATA box, Poli-A site and Cap site were not observed. Furthermore, the phylogenetic analysis using the $630 \mathrm{bp}$ amplified from the 5 ' $L T R$ segment confirmed the occurrence of HTLV-Ilc (Figure 3).

The sequence analysis of the Kararao samples exhibited a high genetic similarity (99.9\%) between the mother and child samples (KAA8878 and KAA8879, respectively). The only difference was a deletion of two nucleotides (TC) in the mother sequence (positions 236 and 237). This result shows a strong evidence of vertical transmission.

\section{DISCUSSION}

The geographical distribution of HTLV-II in the Amazon region of Brazil exhibits the largest area worldwide, it is mainly distributed among native Indian groups and it is in a current epidemiological process of dissemination into urban areas 17182431 . Transmission of the virus is primarily through blood transfusion, drug usage, sexual intercourse and breast feeding 59192028 .
Seroprevalence of HTLV-II among urban communities is commonly low with the exception of some groups with specific behavior that contribute for the transmission of the virus ${ }^{59}$. A high prevalence of HTLV-II infection has been reported among IVDU from USA $^{622}$. Similarly, HTLV-II infection was found in $14.6 \%$ of IVDU from Dublin, Ireland ${ }^{5}$. 
U3

MO

KAA8 878

KAA 8879

KAA8 883

MO

KAA8878

KAA8879

KAA8883

MO

KAA8 878

KAA8 879

KAA8 883

MO

KAA8 878

KAA8879

KAA8883

MO

KAA8878

KAA8 879

KAA8 883

KAA8878

KAA8879

KAA8883

KAA8878

KAA8 879

KAA88 83

MO

KAA88 78

KAA8879

KAA 8883

MO

KAA8878

KAA8 879

KAA8 883

KAA8878

KAA8879

KAA8883

KAA8 878

KAA8 879

KAA 8883
$21 \mathrm{pb}$ (repetitions)

AAGTAAAGGC TCTGACGTCT CCCCCTTTTT TTAGGAACTG AAACCACGGC CCTGACGTCC 60

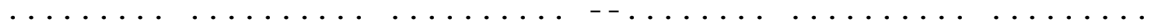

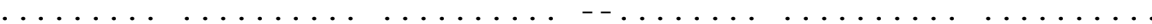

CTCCCCCCT- AGGAAC-AGG AACAGCTCTC CAGAAAAAAA TAGACCTCAC CCTTACCCAC 120

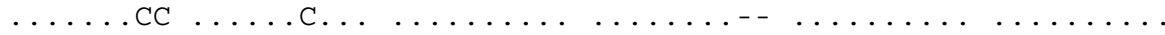

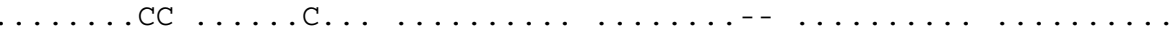

$21 \mathrm{pb}$ (repetitions)

TTCCCCTAGC GCTGAAAAAC AAGGCTCTGA CGATTACCCC CTGCCCATAA AATTTGCCTA 180

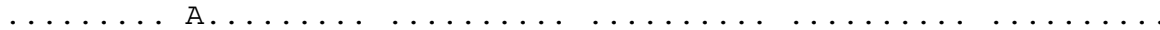

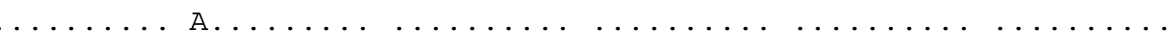

$\ldots \ldots A$

TATA box

Cap $\cdots \cdots \Gamma_{R}$

GTCAAAATAA AAGATGCCGA GTCTATAAAA GCGCAAGGAC AGTTCAGGAG GTGGCTCGCT 240

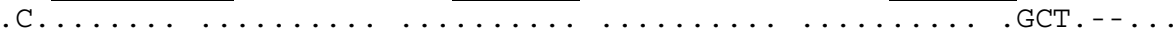

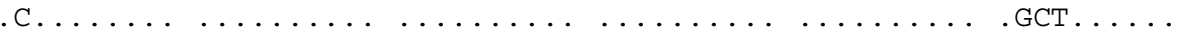

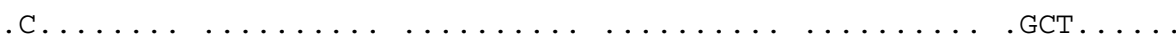

CCCTCACCGA CCCTCTGGTC ACGGAGACTC ACCTTGGGGA TCCATCCTCT CCAAGCGGCC 300

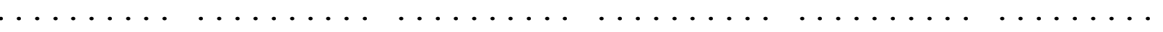

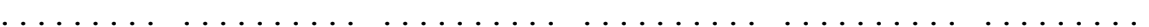

TCGGTTGAGA CGCCTTCCGT GGGA-CCGTC TCCCGGCCTC GGCACCTCCT GAACTGCTCC 360

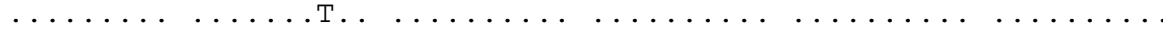

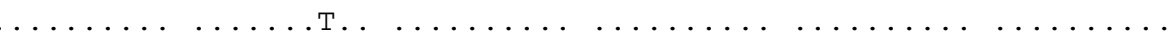

TCCCAAGgTA AGTCTCCTCT CAgGTCGAGC TCGGCTGCCC CTTAGGTAGT CGCTCCCCGA 420

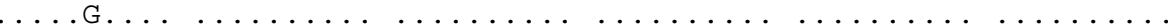

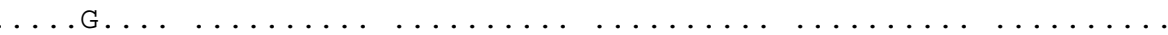

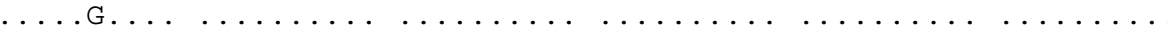

GGGTCTTTAG AGACACCCGG GTTTCCGCCT GCGCTCGGCT AGACTCTGCC TTAAACTTCA 480

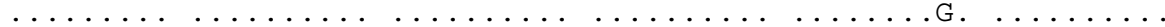

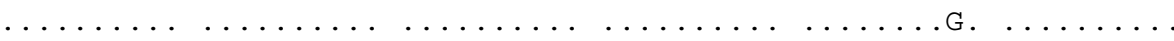

广ं

CTTCCGCGTT CTTGTCTCGT TCTTTCCTCT TCGCCGTCAC TGAAAACGAA ACCTCAACGC 540

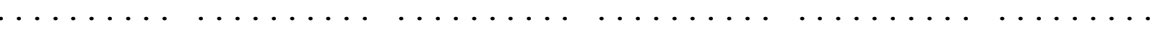

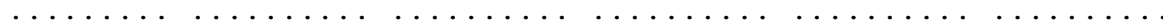

CGCCCTCTTG GCAGGCGT-- CCCGGGGCCA ACATAC-GCC GTGGAG-CGC AGCAAGGGCT 600

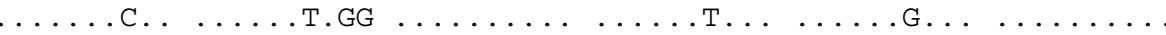

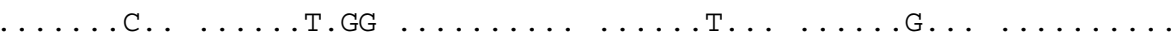

$\ldots \ldots$. . . . . . . . . . . . . . . . . . . . . . . . .

AGGGCTTCCT GAACCTCTCC GGGAGAGGTC 630

$\ldots \ldots \ldots \ldots \ldots \ldots \ldots \ldots \ldots \ldots \ldots \ldots \ldots \ldots$

Figure 2 - Nucleotide sequences of the 5' LTR region obtained from Kararao samples of the Amazon region of Brazil. The sequences are compared with HTLV-lla prototype (Mo). 


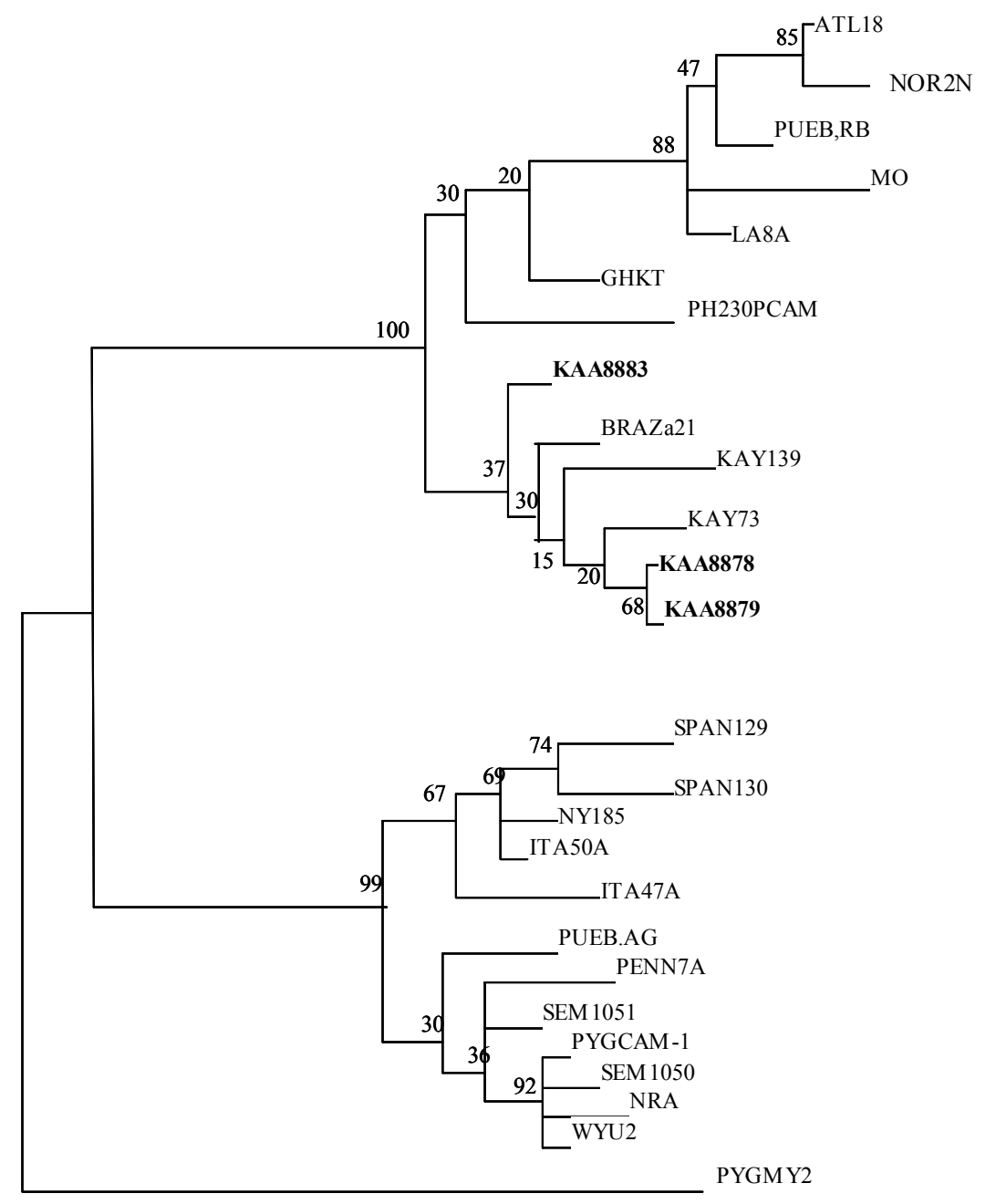

Figure 3 - Unrooted phylogenetic tree showing the evolutionary relationship of HTLV-ll reported so far including newly sequenced isolates from the present study (Amrerindian subjects: KAA8883, KAA8878, $K A A 8879)$. The tree was constructed by $N-J$ method after alignment of 630 nucleotide of the 5' LTR region. The statistical support was applied using 2000 bootstrap replicate.

HTLV-II infection is endemic in other Amerindian populations from North, Central and South America ${ }^{29}$. In Colombia, 29/92 (31,5\%) Guahibo Indians were found with specific antibodies to HTLV-II'1 . The Yaruro and Guahibo indians of Venezuela showed a high prevalence of $61 \%$ of antibodies to HTLV-IIb ${ }^{23}$. On the other hand, a low prevalence of $2 \%$ was observed among the Mapuche tribe from Argentina, but, the infection ranged from 4\% to $44 \%$ in different villages of the Gran Chaco, Paraguai ${ }^{10}$.

RFLP analysis of $p X$ and env genes and the nucleotide sequence analysis of $5^{\prime} L T R$, followed by phylogenetic inference, exhibited the presence and dissemination of a new molecular subtype named HTLV$\mathrm{IIC}^{717}$. Previous epidemiological studies among native Indians from Brazil have provided evidence of intrafamilial and vertical transmission of HTLV-IIc among several families of the Kubenkokre and the Xicrin, both Kayapo, Je speaking community groups ${ }^{217}$. The present paper reports the serological and molecular evidences that confirm vertical transmission of HTLV-Ilc between mother and child within the Kararao village, another Kayapo group.

A strong molecular evidence of mother-to-child transmission of HTLV-IIc is provided when comparing the 5'LTR nucleotide sequence of the HTLV-II virus of the mother and the child. There was a high genetic similarity of $99.9 \%$ between the two samples with a single difference of a deletion of two nucleotides in the maternal sequence (Figure 2). Considering that the two nucleotides were present in two of the three virus sequences of the Kararao tribe (including the child), it is possible that the deletion could have occurred after the vertical transmission from mother-to-child. 
Furthermore, it is also possible that the HTLV-Ilc selected from individual KAA8878 was one of a pool of naturally infecting virus, and the cloning procedures might have had the chance to preferentially select clones exhibiting the deletion instead.

Endemicity of HTLV-II, particularly among small communities is maintained by a specific process of virus latency alternating with a productive period, a mechanism that is in large part responsible for long lasting infections. Although the actual route of transmission of HTLV-Ilc is unknown, breast feeding would appear the most likely. Breast feeding is a common practice in several native populations and the main source of nutrition for the infants. Furthermore, it is a common procedure that women breast-feed other children, contributing to the dissemination of HTLV-II. The source of the mother infection is unknown. It is probable that it occurred by intrafamilial transmission, but it could not be successfully proven since her parents were already dead and her husband did not exhibit serorreactivity to HTLV-II.

The present paper confirms the widespread distribution of HTLV-Ilc in the Amerindian tribes of Brazil and emphasizes the need to better understand the routes of transmission and maintenance of HTLV in small communities.

\section{ACKNOWLEDGMENTS}

To the Kararao Indians who participated in the present work. Collection of samples is gratefully acknowledged to W. Monteiro and E.S. Abrahim. The present work was partially supported by grants from the Universidade Federal do Pará and NIH, USA.

\section{REFERENCES}

1. Biggar RJ, Taylor ME, Neel JV, Hjelle B, Levine PH, Black FL, Shaw GM, Sharp PM, Hahn BH. Genetic variants of Tlymphotropic virus type II in American Indian Groups. Virology, 216: 165-173, 1996.

2. Black FL, Biggar RJ, Lal RB, Gabbai AA, Vieira Filho JPB. Twentyfive years of HTLV type II follow-up with a possible case of tropical spastic paraparesis in the Kayapo, a Brazilian Indian Tribe. AIDS Research and Human Retroviruses, 12: 1623-1627, 1996.

3. Cabot EL, Beckenbach AT (1989). Simultaneous editing of multiplic nucleic acid and protein sequences with ESEE. Computer Apply Bioscience 5:233-234, 1989.

4. Duenas-Barajas E, Bernal JE, Vaugth DR, Nerurkar VR, Sarmiento P, Ynagihara R, Gajdusek DC. Human retroviruses in Amerindians of Colombia: High prevalence of human T-cell lymphotropic virus type II infection among the Tunebo Indians. American Journal of Tropical Medicine and Hygiene, 49: 657663, 1993.

5. Egan JF, O'Leary B, Lewis M, Mulcahy F, Sheehy N, Hasegawa H, Fitzpatrick F, O'Connor JJ, O'Riondan J, Hall, WW. High rate of human T-lymphotropic virus type Ila infection in HIV type 1infected intravenous drug abusers in Ireland. AIDS Research and Human Retroviruses, 15: 699-705, 1999.

6. Ehrlich GD, Glaser JB, La Vigne K, Quan D, Mildvan D, Sninsk JJ, Kwok S, Papsider L, Poiesz BJ. Prevalence of human T-cell leukemia/lymphoma virus (HTLV) type infection among high-risk individuals: type specific identification of HTLVs by polymerase chain reaction. Blood, 74: 1658-1664, 1989.

7. Eiraku N, Novoa P, Ferreira MC, Monken C, Ishak R, Ferreira OC, Zhu SW, Lorenco R, Ishak M, Azevedo V, Guerreiro JF, Pombo de Oliveira M, Loureiro P, Hammerschlak N, ljichi S, Hall WW. Identification and characterization of a new and distinct molecular subtype of human T-cell lymphotropic virus type 2. Journal of Virology., 70: 1481-1492, 1996.

8. Felsenstein J. PHYLIP - Phylogeny Inference Package. Version 3.5c. University of Washington, Seattle, 1993.

9. Ferreira Jr. OC, Vaz RS, Carvalho MB, Guerra C, Fabron AL, Rosemblit J, Hamerschlak N. Human T-lymphotropic virus type I and type II infections and correlation with risk factors in blood donors from Sao Paulo, Brazil. Transfusion, 35: 258-263, 1995.

10. Ferrer JF, Esteban E, Dube S, Basombrio MA, Segovia A, PeraltaRamos M, Dube DK, Sayre K, Aguayo N, Hengst J, Poiesz BJ. Endemic infection with human T-cell leukemia/lymphoma virus type Ilb in Argentinean and Paraguayan Indians: epidemiology and molecular characterization. Journal of Infectious Diseases, 174: 944-953, 1996.

11. Fujiyama C, Fugiyoshi T, Miura T, Yashaki S, Matsumoto D, Zaninovik V, Blanco O, Harrington Jr. W, Byrnes JJ, Hayami M, Sonoda S. A new endemic focus of human T-lymphotropic virus type II carriers among Orinoco natives in Colombia. Journal of Infectious Diseases, 169:1075-1077, 1993.

12. Goubau P., Liu H., Lange G.G., Vandamme A.M., Desmyter J. HTLV-II seroprevalence in Pygmies across Africa since 1970. AIDS Research and Human Retroviruses, 9: 709-712, 1993.

13. Hall WW, Kubo T, ljichi S, Takahashi H, Zhu SW. Human T-cell leukemia virus type II (HTLV-II): emergence of an important newly recognized pathogen. Seminars of Virology. 5: 165-178, 1994.

14. Hall WW, Takahashi H, Liu C, Kaplan MH, Sheewind O, ljichi S, Nagashima K, Gallo RC. Multiple isolates and characteristics of human T-cell leukemia virus type II. Journal of Virology, 66:2456-2463, 1992.

15. Harrington WJ, Sheremata W, Hjelle B, Dube DK, Bradshaw P, Foung SKH, Snodgrass S, Toedter A, Cabral L, Poiesz B. (1993). Spastic ataxia associated with human T-cell lymphotropic virus type II infection. Annals of Neurology, 33: 411-414, 1993.

16. Hjelle B, Zhu SW, Takahashi H, ljichi S, Hall WW. Endemic human T cell leukemia virus type II infection in Southwestern US Indians involves two prototypes variants of virus. Journal of Infectious Diseases, 168: 737-740, 1993.

17. Ishak R, Harrington Jr. WJ, Azevedo VN, Eiraku N, Ishak MOG, Guerreiro JF, Santos SEB, Kubo T, Monke C, Alexander S, Hall W.W. Identification of human T-cell lymphotropic virus type lla infection in the Kayapo, an indigenous population of Brazil. AIDS Research and Human Retroviruses,11: 813-821, 1995.

18. Ishak R, Ishak MOG, Azevedo VN, Santos DEM, Vallinoto ACR, Saraiva JCP, Crescente JA, Hall WW. Detection of HTLV-Ila in 
blood donors in an urban area of the Amazon Region of Brazil (Belem, Para). Revista da Sociedade Brasileira de Medicina Tropical, 31: 193-197, 1998.

19. Kaplan JE, Abrams E, Shaffer N, Cannon RO, Kaul A, Krasinski K, Bamji M, Hartley TM, Roberts B, Kilbourne B, Thomas P, Rogers M, Heneine W. Low risk of mother-to-child transmission of human T-cell lymphotropic virus type II in non-breast-fed infants. Journal of Infectious Diseases, 166: 892-895, 1992.

20. Lal RB, Gongora-Biachi RA, Pardi D, Switzer WM, Goldman I, Lal AA. Evidence for mother-to-child transmission of human Tcell lymphotropic virus type II. Journal of Infectious Diseases, 168: 586-591, 1993.

21. Lee $H$, Idler KB, Swanson P, Aparicio JJ, Chin KK, Lax JP, Nguyen M, Mann T, Leckie G, Zanetti A, Marinucci G, Chen ISY, Rosenblatt JD. Complete nucleotide sequence variation of HTLV-II isolates from U.S. blood donors and U.S. and Italian IV drug users. Virology, 196: 57-69, 1993.

22. Lee HH, Swanson P, Shorty VS, Zack JA, Rosemblatt JD, Chen ISY. High rate of HTLV-II infection in seropositive intravenous drug abusers in New Orleans. Science, 244: 471-575, 1989.

23. Leon-Ponte M, Echeverria de Perez G, Bianco N, Hengst J, Dube S, Love J, Poiesz BJ. Endemic infection with HTLV-IIb in Venezuelan Indians: molecular characterization. Journal of Acquired Immune Deficiency Syndromes and Human Retrovirology, 17: 458-464, 1998.

24. Maloney EM, Biggar RJ, Neel JV, Taylor ME, Hahn BH, Shaw GM, Blattner WA. Endemic Human T cell lymphotropic virus type II infection among isolated Brazilian Amerindians. Journal of Infectious Diseases, 166: 100-107, 1992.
25. Mauclère $P$, Mahieux R, Garcia-Calleja JM, Salla $R$, Tekaia $F$, Millan J, de Thé G, Gessain A. A new HTLV-II subtype a isolate in an HIV-1 infected prostitute from Cameroon, Central Africa. AIDS Research and Human Retroviruses, 11: 989-993, 1995.

26. Murphy EL. HTLV-II related disease. Lancet, 341:88, 1993.

27. Salemi M, Vandamme AM, Gradozzi C, Van Laethem K, Cattaneo E, Taylor G, Casoli C, Goubau P, Desmyter J, Bertazzoni U. Evolutionary rate and genetic heterogeneity of human T-cell lymphotropic virus type II (HTLV-II) using isolates from European injecting drugs users. Journal of Molecular Evolution, 46: 602-611, 1998.

28. Segurado AA, Malaque CM, Sumita LM, Pannuti CS, Lal RB. Laboratory characterization of human T-cell lymphotropic virus types 1 (HTLV-1) and 2 (HTLV-2) infections in blood donors from Sao Paulo, Brazil. American Journal of Tropical Medicine and Hygiene, 57: 142-148, 1997.

29. Switzer WM, Pieniazek D, Swanson P, Sandal HH, Soriano V, Khabbaz RF, Kaplan JE, Lal RB, Heneine W. Phylogenetic relationship and geographic distribution of multiple human T-cell lymphotropic virus type II subtypes. Journal of Virology, 69: 621-632, 1995.

30. Tuppin P, Gessain A, Kazanji M, Mahieux R, Cosnefroy J, Tekai F, Georges-Courbot M, Georges A, de Thé G. Evidence in Gaboon for an intrafamilial clustering with mother-to-child and sexual transmission of a new molecular variant of human T-lymphotropic virus type-Il subtype B. Journal of Medical Virology, 48: 22-32, 1996.

31. Vallinoto ACR., Azevedo VN, Santos DEM, Caniceiro S, Mesquita FCL, Hall WW, Ishak MOG, Ishak R. Serological Evidence of HTLV-I and HTLV-II Co-infections in HIV-1 positive patients in Belem, State of Para, Brazil. Memórias do Instituto Oswaldo Cruz 93: 407-409, 1998. 